\title{
PEMANFAATAN METODE TECHNIQUE FOR ORDER PREFERENCE BY SIMILIARITY TO IDEAL SOLUTION (TOPSIS) UNTUK MENENTUKAN PELANGGAN TERBAIK
}

\author{
M. Abu Jihad Plaza R \\ Teknik Informatika \\ STMIK Surya Intan \\ Jl. Ibrahim Syarief No. 107 Kotabumi Lampung Utara \\ E-mail : abujihad83@gmail.com
}

\begin{abstract}
ABSTRAK
Persaingan di dunia industri semakin ketat seiring dengan meningkatnya pertumbuhan industri. Persaingan ini mengakibatkan setiap perusahaan harus lebih jeli dalam melakukan pemilihan pelanggan terbaik penerima reward untuk meningkatkan loyalitas pelanggan sehingga semua tujuan yang ingin dicapai dapat terlaksana dengan baik.

Penilaian untuk tiap pelanggan tentunya didasarkan pada kriteria atau kontribusi masing-masing pelanggan, karena itu tiap pelanggan memiliki nilai yang berbeda bagi perusahaan tergantung pada kriteria atau kontribusi yang diberikan pelanggan tersebut bagi perusahaan. PT. Indomarco Adhi Prima Kotabumi merupakan perusahaan yang bergerak dibidang pendistribusian barang-barang pemenuhan kebutuhan ke gerai-gerai yang terkait, bukanlah hal yang mudah tentunya untuk melakukan penilaian pelanggan bagi perusahaan, dalam penentuan pendukung keputusan memilih pelanggan terbaik PT. Indomarco Adhi Prima kurang tepat dan optimal sehingga menjadi masalah dalam memilih pelanggan terbaik yang tepat sasaran.

Berdasarkan analisis permasalahan diatas, maka diperlukan suatu sistem yang dapat membantu PT. Indomarco Adhi Prima Kotabumi dalam mengambil keputusan pemilihan pelanggan terbaik dengan waktu yang tepat tanpa mengurangi kualitas dari keputusan yang dihasilkan. Sistem ini yang kemudian bisa disebut Sistem Pendukung Keputusan (SPK) dalam hal ini penulis menggunakan metode TOPSIS dan diharapkan dapat membantu PT. Indomarco Adhi Prima Kotabumi dalam melakukan penentuan pelanggan terbaik sehingga dapat menghasilkan informasi yang dapat berguna bagi perusahan dalam hal penilaian dan pemilihan pelanggan terbaik.
\end{abstract}

Kata Kunci : SPK, TOPSIS, Pelanggan

\section{PENDAhUluAN}

Persaingan di dunia industri semakin ketat seiring dengan meningkatnya pertumbuhan industri. Persaingan ini mengakibatkan setiap perusahaan harus lebih jeli dalam melakukan pemilihan pelanggan terbaik penerima reward untuk meningkatkan loyalitas pelanggan sehingga semua tujuan yang ingin dicapai dapat terlaksana dengan baik.

Penilaian untuk tiap pelanggan tentunya didasarkan pada kriteria atau kontribusi masing- masing pelanggan, karena itu tiap pelanggan memiliki nilai yang berbeda bagi perusahaan tergantung pada kriteria atau kontribusi yang diberikan pelanggan tersebut bagi perusahaan. PT. Indomarco Adhi Prima Kotabumi merupakan perusahaan yang bergerak dibidang pendistribusian barang-barang pemenuhan kebutuhan ke gerai-gerai yang terkait, bukanlah hal yang mudah tentunya untuk melakukan penilaian pelanggan bagi perusahaan, dalam penentuan pendukung keputusan memilih pelanggan terbaik PT. Indomarco Adhi Prima 
kurang tepat dan optimal sehingga menjadi masalah dalam memilih pelanggan terbaik yang tepat sasaran.

Berdasarkan analisis permasalahan diatas, maka diperlukan suatu sistem yang dapat membantu PT. Indomarco Adhi Prima Kotabumi dalam mengambil keputusan pemilihan pelanggan terbaik dengan waktu yang tepat tanpa mengurangi kualitas dari keputusan yang dihasilkan. Sistem ini yang kemudian bisa disebut Sistem Pendukung Keputusan (SPK) dalam hal ini penulis menggunakan metode Technique For Order Preference By Similiarity To Ideal Solution (Topsis) diharapkan dapat membantu PT. Indomarco Adhi Prima Kotabumi dalam melakukan penentuan pelanggan terbaik sehingga dapat menghasilkan informasi yang dapat berguna bagi perusahan dalam hal penilaian dan pemilihan pelanggan terbaik.

\section{METODE PENELITIAN}

\subsection{Pengertian Sistem Pendukung Keputusan} (SPK)

Sistem pendukung keputusan merupakan sistem informasi interaktif yang menyediakan informasi, pemodelan dan manipulasi data. Sistem itu digunakan untuk membantu pengambilan keputusan dalam situasi yang semiterstruktur dan situasi tidak terstruktur, dimana tak seorang pun tahu secara pasti bagaimana keputusan seharusnya dibuat [1].

SPK dapat terdiri dari empat buah komponen, yaitu :

a. Subsistem Manajemen Data

b. Subsistem Manajemen Model

c. Subsistem Antarmuka

d. Subsistem Manajemen Berbasis Pengetahuan

\subsection{Pengertian Pelanggan}

Pelanggan adalah individu atau kelompok yang membeli sebuah produk atau jasa berdasarkan keputusan mereka yang didasarkan atas pertimbangan dari segi manfaat dan harga produk atau jasa tersebut [2].

\subsection{Macromedia Dreamweaver 8}

Macromedia Dreamweaver 8 merupakan alat desain web komprehensif yang disukai oleh para profesional web, Macromedia Dreamweaver adalah program untuk membuat halaman web atau dokumen web. Berbicara dokumen web disini adalah dokumen HTML [3]

\subsection{Pengertian Metode Technique For Order Preference by Similiarity to Ideal Solution (TOPSIS)}

TOPSIS menggunakan prinsip bahwa alternatif yang terpilih harus mempunyai jarak terdekat dari solusi ideal positif dan terjauh dari solusi ideal negatif dari sudut pandang geometris dengan menggunakan jarak Euclidean untuk menentukan kedekatan relatif dari suatu alternatif dengan solusi optimal [4]. Solusi ideal positif didefinisikan sebagai jumlah dari seluruh nilai terbaik yang dapat dicapai untuk setiap atribut, sedangkan solusi negatif-ideal terdiri dari seluruh nilai terburuk yang dicapai untuk setiap atribut.

Pada penelitian ini untuk menentukan pelanggan terbaik menggunakan metode Technique For Order Preference by Similiarity to Ideal Solution (TOPSIS) dengan tahap sebagai berikut :

a. Membangun normalized decision matrix

$$
\mathrm{R}_{\mathrm{ij}}=\frac{x_{i j}}{\sqrt{\sum_{i=1}^{m} x_{i j}^{2}}}
$$

Menentukan solusi ideal positif dan solusi ideal negatif Solusi ideal positif dinotasikan dengan

b. A+ dan solusi ideal negatif dinotasikan dengan A-, sebagai berikut :

$$
\begin{aligned}
& \mathrm{y}_{\mathrm{ij}}=\text { wi.rij } ; \text { dengan } \mathrm{i}=1,2, \ldots, \mathrm{m} ; \text { dan } \\
& \mathrm{j}=1,2, \ldots, \mathrm{n} \\
& \mathbf{A}^{+}=\left(\mathbf{y}_{1}^{+}, \mathbf{y}_{\mathbf{2}}^{+}, \ldots, \mathbf{y}_{\mathbf{n}}^{+}\right) \\
& \mathbf{A}^{-}=\left(\mathbf{y}_{\mathbf{1}}^{-}, \mathbf{y}_{\mathbf{2}}^{-}, \ldots, \mathbf{y}_{\mathbf{n}}^{-}\right)
\end{aligned}
$$

c. Menentukan jarak antara nilai setiap alternatif dengan matriks solusi ideal positif dan solusi ideal negatif.

$$
\mathrm{D}_{\mathrm{i}}^{+}=\sqrt{\sum_{i=1}^{n}\left(y_{i}{ }^{+}-y_{i j}\right)^{2}} ; \mathrm{i}=1,2, \ldots, \mathrm{m}
$$

d. Menentukan Nilai preferensi untuk setiap alternatif, dengan rumus sebagai berikut :

$$
\mathbf{V i}=\frac{D_{i}^{-}}{D_{i}^{-}+D_{i}^{+}} ; \mathbf{i}=1,2, \ldots, \mathbf{m}
$$

\section{HASIL DAN PEMBAHASAN}

Hasil dari penelitian ini didapat dengan cara observasi, wawancara dan studi pustaka yang dilakukan selama berada di tempat penelitian 
diantaranya berupa data-data yang akurat dan bentuk fisik

\subsection{Tahapan Metode (TOPSIS)}

Adapun tahapan - tahapan dalam proses perhitungan menggunakan metode TOPSIS sebagai berikut :

a. Bobot Kriteria

Bobot dalam setiap kriteria dalam penilaian pelanggan terbaik dapat dilihat pada Tabel 1

Tabel.4.1. Bobot Kriteria

\begin{tabular}{|c|l|c|}
\hline No & \multicolumn{1}{|c|}{ Kriteria } & Bobot \\
\hline 1 & Total belanja per3 bulan (C1) & $30 \%$ \\
\hline 2 & Cara pembayaran (C2) & $15 \%$ \\
\hline 3 & Lama berlanggan (C3) & $30 \%$ \\
\hline 4 & Jumlah Tunggakan (C4) & $25 \%$ \\
\hline \multicolumn{2}{|c|}{ Jumlah } & $100 \%$ \\
\hline
\end{tabular}

b. Bobot Nilai Kriteria

Memeberikan nilai pada setiap kriteria yang sudah ditentukan dapat dilihat pada Tabel 2, 3, 4 dan 5

Tabel 2 Total Belanja Per Tiga Bulan (C1)

\begin{tabular}{|c|l|c|}
\hline No $_{\mathbf{0}}$ & \multicolumn{1}{|c|}{ Keterangan } & Nilai \\
\hline 1 & $<$ Rp. 8.000 .000 & 1 \\
\hline 2 & Rp. $8.000 .000-9.000 .0000$ & 2 \\
\hline 3 & Rp. $9.000 .000-10.000 .000$ & 3 \\
\hline 4 & $>$ Rp. 10.000 .000 & 4 \\
\hline
\end{tabular}

Tabel 3 Cara Pembayaran (C2)

\begin{tabular}{|c|l|c}
\hline No & \multicolumn{1}{|c|}{ Keterangan } & Nilai \\
\hline 1 & Kredit & 2 \\
\hline 2 & Cash & 4 \\
\hline
\end{tabular}

Tabel 4 Lama Berlangganan (C3)

\begin{tabular}{|c|l|c}
\hline No & \multicolumn{1}{|c|}{ Keterangan } & Nilai \\
\hline 1 & 10 Tahun & 1 \\
\hline 2 & 15 Tahun & 2 \\
\hline 3 & 20 Tahun & 3 \\
\hline
\end{tabular}

Tabel 5 Jumlah Tunggakan (C4)

\begin{tabular}{|c|l|c|}
\hline No & \multicolumn{1}{|c|}{ Keterangan } & Nilai \\
\hline 1 & $>$ Rp. 5.000 .000 & 1 \\
\hline 2 & Rp. $1.000 .000-2.000 .0000$ & 2 \\
\hline 3 & Rp. 800.000 & 3 \\
\hline 4 & Rp. 0 & 4 \\
\hline
\end{tabular}

c. Rekap Nilai Total Belanja Per Tiga Bulan Data nilai total belanja per tiga bulan diperoleh dari transaksi selama 3 bulan terakhir yaitu bulan April, Mei dan Juni 2018, dapat dilihat pada Tabel 6

Tabel.6. Nilai Total Belanja Per Tiga Bulan

\begin{tabular}{|c|c|c|c|c|c|c|c|c|}
\hline$v_{0}$ & Kode & $N_{0}$ & Apr -18 & Mei-18 & Jun-18 & & ah Total & $\mathrm{cl}$ \\
\hline & 230.002 & Warmo & Rp $\quad 185.389$ & $\begin{array}{ll}\mathrm{Rp} & 182.891\end{array}$ & $\begin{array}{ll}\mathrm{Rp}_{\mathrm{p}} & 72.485\end{array}$ & $\mathrm{Rp}$ & 440.765 & 1 \\
\hline & 230.067 & Bu Yuli & $\operatorname{Rp} \quad 391.555$ & $\mathrm{Rp}$ & $\begin{array}{ll}\text { Rp } \quad 591.469\end{array}$ & $\mathrm{Rp}$ & 983.024 & 1 \\
\hline 3 & 230.081 & Bu Amanian & Rp 274.735 & $\begin{array}{ll}R_{p p} & 97.888 \\
\end{array}$ & $\operatorname{Rp} \quad 210.544$ & $\mathrm{Rp}$ & 583.167 & 1 \\
\hline 4 & 230.001 & Utami & $\mathrm{Rp}_{\mathrm{p}}$ & Rp 114.036 & $\mathrm{Rp} 118.182$ & $\mathrm{Rp}$ & 232.218 & 1 \\
\hline & 230.039 & Nata & $\mathrm{Rp} \quad 91.817$ & $\begin{array}{lll}R p & 67.345\end{array}$ & $\mathrm{Rp}$ & $R_{p}$ & 159.162 & 1 \\
\hline 6 & 230.077 & Bu Amin Sitit & $\operatorname{Rp} \quad 883.161$ & $\begin{array}{ll}\text { Rp } \quad 175.004 \\
\end{array}$ & Rp 214.928 & $\mathrm{Rp}$ & 1.273 .093 & 1 \\
\hline & 230.236 & Hj. Maymunah & Rp 398.700 & $R_{p} \quad 391.555$ & Rp 484.282 & $\mathrm{Rp}$ & 1.274 .537 & 1 \\
\hline 8 & 230.046 & DepotMunti & Rp 1.473.1110 & $\operatorname{Rp} 1.688 .227$ & Rp 719.092 & $\mathrm{Rp}$ & 3.880 .429 & 1 \\
\hline 9 & 230.096 & Santoso & $\mathrm{Rp}$ & Rp 1.558.037 & Rp 383.398 & $\mathrm{Rp}$ & 1.941 .435 & 1 \\
\hline 10 & 230.221 & Andian & Rp 357.145 & $R_{p}$ & $\operatorname{Rp} 2.019 .826$ & $R p$ & 2.376 .971 & 1 \\
\hline 1 & 230.117 & Umu sariph & $\operatorname{Rpp} 2.201 .059$ & $\operatorname{Rp} 2.250 .771$ & $\operatorname{Rpp} 1.120 .647$ & $\mathrm{Rp}$ & 5.572 .477 & 1 \\
\hline & 200.4 & & 9.864 & 092 & .774 & $\mathrm{Rp}$ & 4.912 .700 & 1 \\
\hline
\end{tabular}

d. Rekap Nilai Cara Pembayaran

Data rekap nilai cara pembayaran didapat dari proses pembayaran toko dalam setiap bulannya dengan cara kredit atau cash, dapat dilihat pada Tabel 7

Tabel 7. Rekap Nilai Cara Pembayaran

\begin{tabular}{|c|c|c|c|c|c|}
\hline No & $\begin{array}{c}\text { Kode } \\
\text { Pelanggan }\end{array}$ & Nama Toke & Jumlah Total & $\underset{\text { Cara }}{\text { Caran }}$ & $\mathrm{C}_{2}$ \\
\hline 1 & 230.002 & Wamo & $\begin{array}{ll}R_{p} & 440.765\end{array}$ & Cas $h$ & 4 \\
\hline 2 & 230.067 & Bu Yuli & $\begin{array}{ll}R_{p} & 983.024\end{array}$ & Cash & \\
\hline 3 & 230.081 & Bu Amanian & $\begin{array}{ll}R_{p} \quad 583.167\end{array}$ & Cash & 4 \\
\hline 4 & 230.001 & Utami & $\begin{array}{ll}R_{p} & 232.218\end{array}$ & Cash & 4 \\
\hline 5 & 230.039 & Nata & $\begin{array}{ll}R_{p} & 159.162\end{array}$ & Cash & 4 \\
\hline 6 & 230.077 & Bu Amin/Siti & $\begin{array}{ll}R p & 1.273 .093\end{array}$ & Kredit & 2 \\
\hline 7 & 230.236 & Hj. Maymunah & $\begin{array}{ll}R_{p} & 1.274 .537\end{array}$ & Kredit & 2 \\
\hline 8 & 230.046 & Depot Munti & $\begin{array}{ll}R_{p p} & 3.880 .429\end{array}$ & Kreditr & 2 \\
\hline 9 & 230.096 & Samtoso & $R_{p} \quad 1.941 .435$ & Kredit & 2 \\
\hline 10 & 230.221 & Andiam & $R_{p} \quad 2.376 .971$ & Kredit & 2 \\
\hline 11 & 230.117 & Umu saripah & $\begin{array}{ll}R_{p} & 5.572 .477\end{array}$ & Kredit & 2 \\
\hline 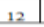 & 200 & Bumi Ja & 2.700 & Kredit & 2 \\
\hline
\end{tabular}

e. Rekap Nilai Lama Berlangganan

Data nilai lama berlangganan didapat dari lama toko berlanganan didapat dari kode pelanggan, jika kode 3 digit berarti 20 tahun berlangganan kode 4 digit berarti 15 tahun berlangganan dan jika kode 6 digit berarti 10 tahun berlangganan, dapat dilihat pada tabel 8.

Tabel 8. Rekap Nilai Lama Berlangganan 


\begin{tabular}{|l|c|l|c|c|}
\hline No & $\begin{array}{c}\text { Kode } \\
\text { Pelanggan }\end{array}$ & Nama Toko & $\begin{array}{c}\text { Lama Berlangganan } \\
\text { (Tahun) }\end{array}$ & C3 \\
\hline 1 & 230.002 & Wamo & 10 & 1 \\
\hline 2 & 230.067 & Bu Yuli & 10 & 1 \\
\hline 3 & 230.081 & Bu Amanian & 10 & 1 \\
\hline 4 & 230.001 & Utami & 10 & 1 \\
\hline 5 & 230.039 & Nata & 10 & 1 \\
\hline 6 & 230.077 & Bu Amin/Siti & 10 & 1 \\
\hline 7 & 230.236 & Hj. Maymunah & 10 & 1 \\
\hline 8 & 230.046 & Depot Munti & 10 & 1 \\
\hline 9 & 230.096 & Santoso & 10 & 1 \\
\hline 10 & 230.221 & Andian & 10 & 1 \\
\hline 11 & 230.117 & Umu saripah & 10 & 1 \\
\hline 12 & 200.418 & Bumi Jaya & 10 & 1 \\
\hline
\end{tabular}

f. Rekap Nilai Jumlah Tunggakan

Data nilai jumlah tunggakan didapat dari berapa jumlah tunggakan pelanggan kepada perusahaan, dapat dilihat pada Tabel 9.

Tabel 9. Rekap Nilai Jumlah Tunggakan

\begin{tabular}{|c|c|c|c|c|c|}
\hline No & $\begin{array}{c}\text { Kode } \\
\text { Pelanggan }\end{array}$ & Nama Toko & \multicolumn{2}{|c|}{$\begin{array}{c}\text { Jumlah } \\
\text { Tunggakan }\end{array}$} & $\mathrm{C} 4$ \\
\hline 1 & 230.002 & Wamo & $\mathrm{Rp}$ & - & 4 \\
\hline 2 & 230.067 & Bu Yuli & $\mathrm{Rp}$ & - & 4 \\
\hline 3 & 230.081 & Bu Amanian & $\mathrm{Rp}$ & - & 4 \\
\hline 4 & 230.001 & Utami & $\mathrm{Rp}$ & 1.132 .218 & 2 \\
\hline 5 & 230.039 & Nata & $\mathrm{Rp}$ & - & 4 \\
\hline 6 & 230.077 & Bu Amin/Siti & $\mathrm{Rp}$ & - & 4 \\
\hline 7 & 230.236 & Hj. Maymunah & $\mathrm{Rp}$ & - & 4 \\
\hline 8 & 230.046 & Depot Munti & $\mathrm{Rp}$ & 1.880 .429 & 2 \\
\hline 9 & 230.096 & Santoso & $\mathrm{Rp}$ & - & 4 \\
\hline 10 & 230.221 & Andian & $\mathrm{Rp}$ & - & 4 \\
\hline 11 & 230.117 & Umu saripah & $\mathrm{Rp}$ & 572.477 & 3 \\
\hline 12 & 200.418 & Bumi Jaya & $\mathrm{Rp}$ & - & 4 \\
\hline
\end{tabular}

\section{g. Rekap Nilai Alternatif Setiap Kriteria}

Tabel 10. Rekap Nilai Alternatif Setiap Kriteia

\begin{tabular}{|r|c|l|c|c|c|c|}
\hline No & $\begin{array}{c}\text { Kode } \\
\text { Pelanggan }\end{array}$ & \multicolumn{1}{|c|}{ Nama Toko } & C1 & $\mathbf{C 2}$ & $\mathbf{C 3}$ & $\mathbf{C 4}$ \\
\hline 1 & 230.002 & Wamo & 1 & 2 & 1 & 4 \\
\hline 2 & 230.067 & Bu Yuli & 1 & 4 & 1 & 4 \\
\hline 3 & 230.081 & Bu Amanian & 1 & 2 & 1 & 4 \\
\hline 4 & 230.001 & Utami & 1 & 4 & 1 & 2 \\
\hline 5 & 230.039 & Nata & 1 & 4 & 1 & 4 \\
\hline 6 & 230.077 & Bu Amin/Siti & 1 & 2 & 1 & 4 \\
\hline 7 & 230.236 & Hj. Maymunah & 1 & 2 & 1 & 4 \\
\hline 8 & 230.046 & Depot Munti & 1 & 2 & 1 & 2 \\
\hline 9 & 230.096 & Santoso & 1 & 2 & 1 & 4 \\
\hline 10 & 230.221 & Andian & 1 & 2 & 1 & 4 \\
\hline 11 & 230.117 & Umu saripah & 1 & 2 & 1 & 3 \\
\hline 12 & 200.418 & Bumi Jaya & 1 & 2 & 1 & 4 \\
\hline
\end{tabular}

Tabel 11. Data Nilai Normalisasi

\begin{tabular}{|l|r|r|r|r|}
\hline Alternatif & \multicolumn{1}{l|}{ C1 } & \multicolumn{1}{l|}{ C2 } & \multicolumn{1}{l|}{ C3 } & \multicolumn{1}{l|}{ C4 } \\
\hline Wamo & 0,0695 & 0,1179 & 0,1270 & 0,1739 \\
\hline Bu Yuli & 0,0695 & 0,2357 & 0,1270 & 0,1739 \\
\hline Bu Amanian & 0,0695 & 0,1179 & 0,1270 & 0,1739 \\
\hline Utami & 0,0695 & 0,2357 & 0,1270 & 0,0870 \\
\hline Nata & 0,0695 & 0,2357 & 0,1270 & 0,1739 \\
\hline Bu Amin/Siti & 0,0695 & 0,1179 & 0,1270 & 0,1739 \\
\hline Hj. Maymunah & 0,0695 & 0,1179 & 0,1270 & 0,1739 \\
\hline Depot Munti & 0,0695 & 0,1179 & 0,1270 & 0,0870 \\
\hline Santoso & 0,0695 & 0,1179 & 0,1270 & 0,1739 \\
\hline Andian & 0,0695 & 0,1179 & 0,1270 & 0,1739 \\
\hline Umu saripah & 0,0695 & 0,1179 & 0,1270 & 0,1304 \\
\hline Bumi Jaya & 0,0695 & 0,1179 & 0,1270 & 0,1739 \\
\hline
\end{tabular}

Menghitung matriks keputusan yang ternormalisasi terbobot menggunakan Persamaan $\mathrm{v}_{\mathrm{ij}}=\mathrm{W}_{\mathrm{j}} * \mathrm{r}_{\mathrm{ij}}$.

Tabel 12. Data Nilai Normalisasi Terbobot

\begin{tabular}{|l|r|r|r|r|}
\hline Alternatif & \multicolumn{1}{l|}{ C1 } & \multicolumn{1}{l|}{ C2 } & \multicolumn{1}{l|}{ C3 } & \multicolumn{1}{l|}{ C4 } \\
\hline Wamo & 2,0156 & 1,7678 & 1,5240 & 2,2609 \\
\hline Bu Yuli & 2,0156 & 3,5355 & 1,5240 & 2,2609 \\
\hline Bu Amanian & 2,0156 & 1,7678 & 1,5240 & 2,2609 \\
\hline Utami & 2,0156 & 3,5355 & 1,5240 & 1,1304 \\
\hline Nata & 2,0156 & 3,5355 & 1,5240 & 2,2609 \\
\hline Bu Amin/Siti & 2,0156 & 1,7678 & 1,5240 & 2,2609 \\
\hline Hj. Maymunah & 2,0156 & 1,7678 & 1,5240 & 2,2609 \\
\hline Depot Munti & 2,0156 & 1,7678 & 1,5240 & 1,1304 \\
\hline Santoso & 2,0156 & 1,7678 & 1,5240 & 2,2609 \\
\hline Andian & 2,0156 & 1,7678 & 1,5240 & 2,2609 \\
\hline Umu saripah & 2,0156 & 1,7678 & 1,5240 & 1,6957 \\
\hline Bumi Jaya & 2,0156 & 1,7678 & 1,5240 & 2,2609 \\
\hline
\end{tabular}

Tabel 13. Solusi Ideal Positif dan Negatif

\begin{tabular}{|c|c|c|c|c|}
\hline Solusi Ideal & $\begin{array}{c}\text { Keuntungan } \\
(\mathbf{C})\end{array}$ & $\begin{array}{c}\text { Biaya } \\
(\mathbf{C} 2)\end{array}$ & $\begin{array}{c}\text { Keuntungan } \\
(\mathbf{C} 3)\end{array}$ & $\begin{array}{c}\text { Biaya } \\
(\mathbf{C} 4)\end{array}$ \\
\hline Solusi Positif & 8,0626 & 1,8898 & 4,5720 & 0,5652 \\
\hline Solusi Negatif & 2,0156 & 3,7796 & 1,5240 & 2,2609 \\
\hline
\end{tabular}

Menghitung nilai kedekatan relatif (closeness coefficient) yang merupakan nilai preferensi untuk setiap alternatif hasilnya dapat dilihat pada Tabel 14

Tabel 14. Data Hasil Seleksi

\begin{tabular}{|l|c|l|l|r|}
\hline \multicolumn{1}{|c|}{ Alternatif } & $\begin{array}{c}\text { Skor } \\
\text { Alkir }\end{array}$ & & \multicolumn{1}{c|}{ Alternatif } & Ranking \\
\hline Nur & 0,8147 & & Nur & 1 \\
\hline Ahmad & 0,7398 & & Ahmad & 2 \\
\hline Ajino & 0,6605 & & Ajino & 3 \\
\hline
\end{tabular}

\subsection{Perhitungan TOPSIS}

Membuat matriks keputusan alternatif $\mathrm{Ai}$ pada setiap kriteria $\mathrm{Fi}$, kemudian dinormalisasi 
menjadi matriks $\mathrm{R}$ (rij) dengan menggunakan Persamaan.

$r_{i j}=\frac{\mathrm{X} x_{i j}}{\sqrt{\sum_{i=1}^{m} x_{i j}^{2}}} i=1,2, \ldots$, m dan $j=1,2, \ldots, n$

Menentukan solusi ideal positif $\left(\mathrm{S}_{\mathrm{j}}^{+}\right)$dan solusi ideal negatif $\left(\mathrm{S}_{\mathrm{j}}^{-}\right)$

$$
\begin{aligned}
& \mathrm{Si}^{+}=\left\{\left(\operatorname{maks} \mathrm{V}_{\mathrm{ij}} \mid \mathrm{j} \in J\right),\left(\min \mathrm{V}_{\mathrm{ij}} \mid \mathrm{j} \in \mathrm{J}^{\prime}\right), \mathrm{i}=1,2,3, \ldots \mathrm{m}\right\}=\left\{\mathrm{V}_{1^{+}}, \mathrm{V}_{2}{ }^{+}, \ldots\right.
\end{aligned}
$$

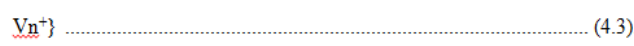

$$
\begin{aligned}
& \mathrm{S}_{\mathrm{i}}^{-}=\left\{\left(\min \mathrm{V}_{\mathrm{ij}} \mid \mathrm{j} \in J\right),\left(\operatorname{maks} \mathrm{V}_{\mathrm{ij}} \mid \mathrm{j} \in \mathrm{J}^{\prime}\right), \mathrm{i}=1,2,3, \ldots \mathrm{m}\right\}=\left\{\mathrm{V}_{1}^{-}, \mathrm{V}_{2}^{-}, \ldots,\right. \\
& \left.\mathrm{Vn}^{-}\right\} \\
& \mathrm{J}=\{\mathrm{j}=1,2,3, \ldots, \mathrm{n} \text { dan } \mathrm{j} \text { merupakan benefit criteria }\} \mathrm{J}^{\prime}=\{\mathrm{j}=1,2,3, \ldots, \mathrm{n} \text { dan } \\
& \text { j merupakan cost criteria } \\
& S_{i}^{+}=\sqrt{\sum_{j=1}^{n}\left(V_{i j}-V_{j}^{+}\right)^{2}, \text { dengan } i=1,2,3, \ldots, m} \\
& S_{i}^{-}=\sqrt{\sum_{j=1}^{n}\left(V_{i j}-V_{j}^{-}\right)^{2}, \text { dengan } i=1,2,3, \ldots, m}
\end{aligned}
$$

\subsection{Menjalankan Program}

a. Menu Log

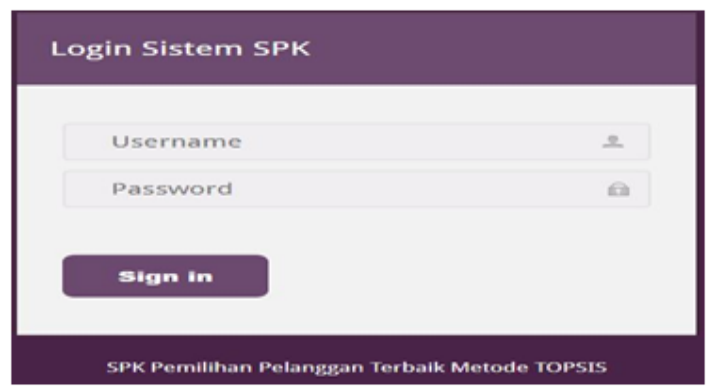

Gambar 1. Menu Login

b. Halaman Admin

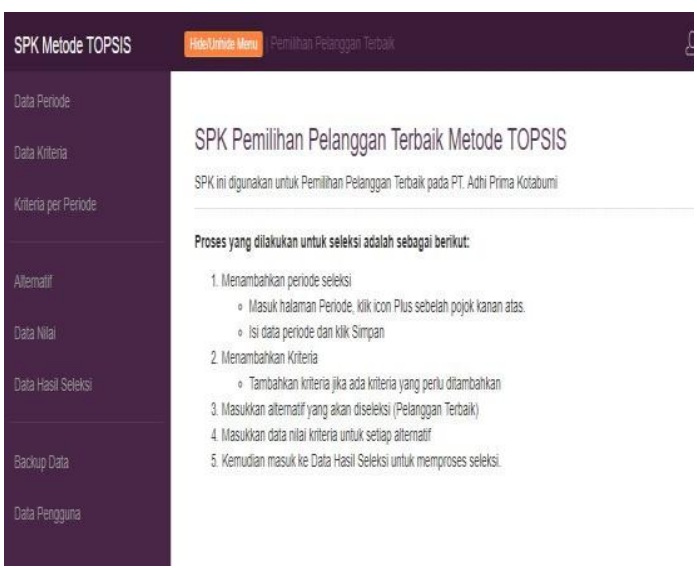

Gambar 2. Halaman Admin c. Data Periode

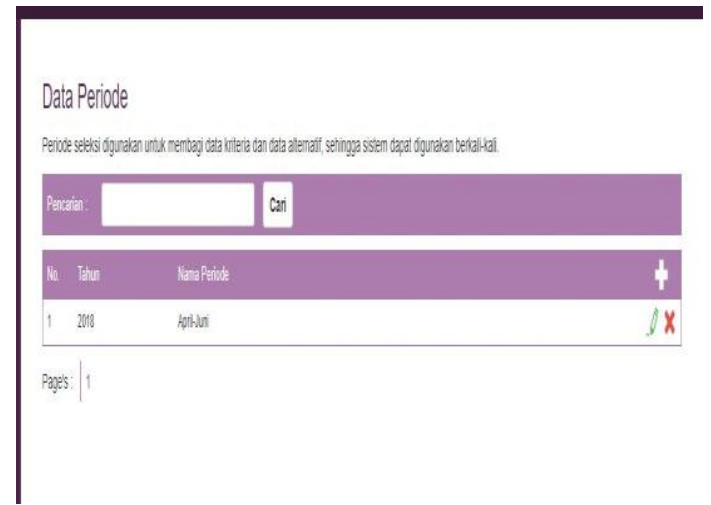

Gambar 3. Data Periode

d. Data Alternatif

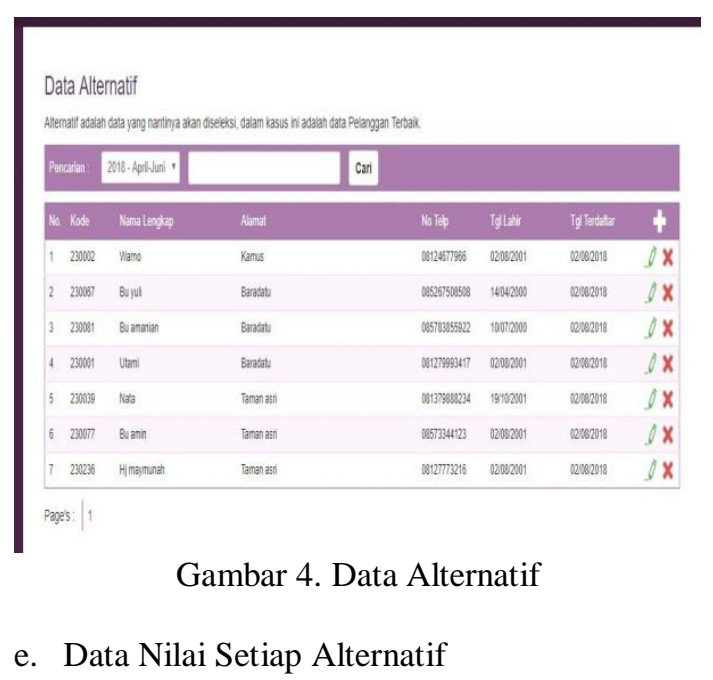

Data Nilai untuk Setiap Alternatif

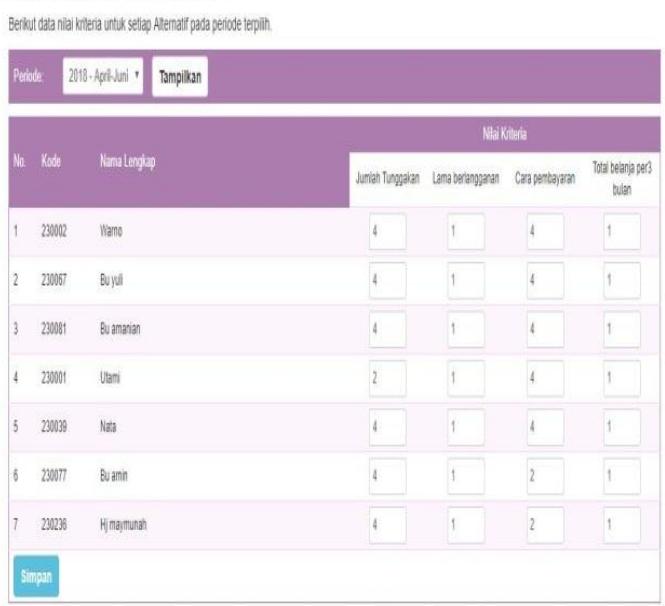

Gambar 5. Data Nilai Setiap Alternatif

f. Data Hasil Seleksi 


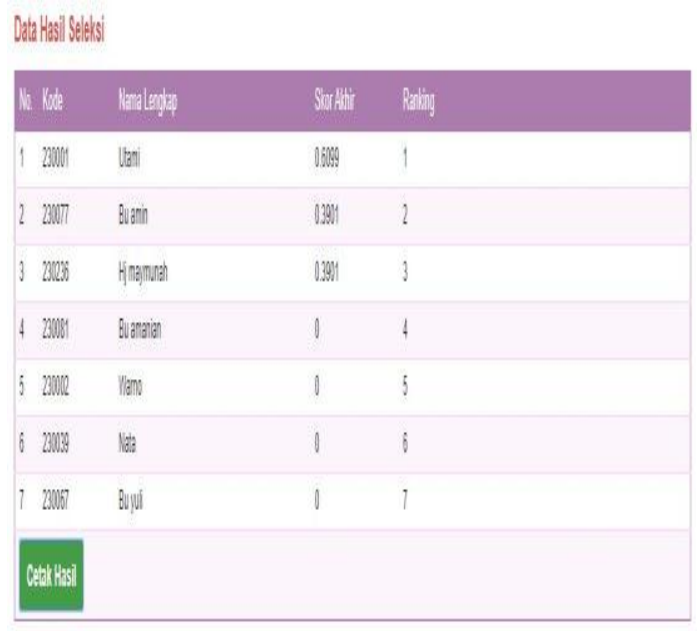

Gambar 6. Data Hasil Seleksi

\section{PENUTUP}

Berdasarkan pembahasan yang telah diuraikan, yaitu tentang penilaian pelanggan terbaik dengan metode Technique For Order Preference By Similarity To Ideal Solution (TOPSIS), maka dapat disimpulkan beberapa hal sebagai berikut:

a. Proses penghitungan pelanggan terbaik menggunakan metode Technique For Order Preference By Similarity To Ideal Solution (TOPSIS), dan di dapat nama pelanggan beserta skor penilaian dan rangking pelanggan terbaik pada PT. Indomarco Adhi Prima.

b. Kriteria yang digunakan untuk penghitungan penilaian pelanggan terbaik dalam penelitian ini menggunakan beberapa kriteria diantaranya : (total belanja per tiga bulan, cara pembayaran, lama berlangganan, dan jumlah tunggakan).

Berdasarkan pembahasan yang ada maka dapat diberikan saran beberapa hal sebagai berikut :

a. Penelitian ini dapat dijadikan sebagai salah satu referensi bagi perusahaan untuk digunakan sebagai acuan dalam pemilihan pelanggan terbaik pada perusahaannya.

b. Dalam penelitian ini penulis hanya membahas tentang penilaian pelanggan terbaik dengan penghitungan menggunakan Technique For Order Preference By Similarity To Ideal Solution (TOPSIS), Oleh karena itu bagi peneliti selanjutnya dapat mengembangkan dengan metode lain pada bidang ilmu dan studi kasus yang berbeda.

\section{DAFTAR PUSTAKA}

[1] Kusrini, Konsep dan Aplikasi SistemPendukung Keputusan. Penerbit Andi, Yogyakarta, 2007.

[2]Greenberg, P, Customer Relationship Management at The Speed of Light: Fourth Edition, McGraw-Hill, 2010.

[3] Madcoms, Aplikasi Web Database Dengan Dreamweaver dan PHP MySQ1, Andi, Yogyakarta, 2011.

[4] Kusumadewi, Sri, Fuzzy Multi -Attribute Decision Making (FUZZY MADM). Penerbit Graha Ilmu, Yogyakarta, 2006 